\section{Legal and Politological Aspects of Competition in Bosnia and Herzegovina as a Paradigm of the European Integration Process}

\author{
Kanita Imamović-Čizmić \\ University in Sarajevo, Faculty of Law
}

\section{Samir Sabljica}

Department for Market Surveillance, Consumer Protection and Competition, Ministry of Foreign Trade and Economic Relations of $\mathrm{BiH}$

$\Gamma$ crossef http://dx.doi.org/10.5755/j01.eis.1.14.25287
EIS 14/2020

Legal and Politological Aspects of Competition in Bosnia and Herzegovina as a Paradigm of the European Integration Process

Submitted 02/2020

Accepted for publication 07/2020

As a country in transition and development, committed to the path towards membership in the European Union, Bosnia and Herzegovina encounters many challenges and obstacles in terms of fulfilling the tasks set before it. Quite complicated governmental and legal arrangement determines the pace of achieving the tasks that are prerequisites for the European Union membership status. By signing the Stabilisation and Association Agreement, Bosnia and Herzegovina assumed the obligation to gradually harmonise the national legislation with the EU legislation in the most important areas related to the internal market. In this context, one of highly important ones is the area of competition law. This paper analyses the quality of solutions provided by the normative and institutional framework of the market competition protection in Bosnia and Herzegovina by using the normative, historical, comparative, and content analysis methods. Basic features of the Stabilisation and Association Agreement between Bosnia and Herzegovina and the EU are presented through a chronological summary of the integration process of $\mathrm{BiH}$ into the EU. The key issue discussed in this paper is that the recent legislative solutions pertaining to the organisation and method of operation of the competition body in Bosnia and Herzegovina, which is the reflection of state arrangement, slows down and impedes the harmonisation of competition regulations in line with the tasks laid down before Bosnia and Herzegovina on its path towards the EU membership. Analytical overview of annual reports on the operation of the Council of Competition as regulatory body in Bosnia and Herzegovina shows that competition is a typical example of the 'crawling' integration of Bosnia and Herzegovina to the EU. It is quite obvious that the lack of political will of the ruling structures slows the integration processes down. This area requires an efficient enforcement of competition regulations whose implementation enables the companies to act in line with the law. Without adequate and prompt amending of the Law on Competition and related by-laws there can be no positive evaluation of the European Commission concerning the progress of Bosnia and Herzegovina.

KEYWORDS: competition law, Competition Law of $\mathrm{BiH}$, Council of Competition of $\mathrm{BiH}$, European integration.

The twentieth century has witnessed the transition process of former communist states in which the market system replaced the process of supervised and planned economy dominated by the state-owned monopolistic economic entities. In relation to that is also the gradually raised awareness on competition as an effective tool for promotion of innovation, increased economic growth rate, and social welfare of these states. Transitional, former communist states, embark on the European integration process as a formula for economic progress and harmonise their legislations and adapt their policies to the European standards. Competition law, as the mech-

\section{Introduction}

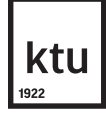

European Integration Studies No. 14 / 2020, pp. 55-68 doi.org/10.5755/j01.eis.1.14.25287 
anism that protects the competition in the internal market of the European Union, is one of the areas the potential candidates have to harmonise with the legal acquis before becoming fully integrated in the European Union. Comparative analyses on the legal frameworks of competition in the countries of Central and Eastern Europe point to comprehensive regulation and systematic implementation as well as advocacy efforts for further harmonisation of legislations in the transition countries (Olaja, 1999). Therefore, appearing as fundamental determinants of the contemporary competition law, under the influence of the process of globalisation, regionalisation, and internationalisation, are the standardisation of legal rules that regulate the area of market competition (Lundqvist, 2014) and the formation of various state bodies and agencies competent for the enforcement of competition law, as well as the need to act on a global level (Lanucara, 2002)(Barak,1981). Standardisation of legal rules reduces alignment costs and is in service of liberalisation, meaning the freedom of movement of goods, services and capital. This standardisation is underlined in the regulations of substantive character that regulate prohibited conduct. That means that certain diversification of competition law in certain states occurs in procedural sense, meaning in the enforcement of competition law and the authorisation of the state body competent for its enforcement. An important role in this standardisation belongs to international organisations (Davidson, 2005, p. 72) and institutions such as the Organisation for Economic Co-operation and Development - OECD and the World Bank, but also the European Union as an economic community of European states.

The introduction of market competition protection regime in transitional countries has opened up a series of related issues for their governments, starting from whether they should introduce the competition-legal regime, which preconditions need to be created for its introduction, which legislative framework is appropriate, and which institutional structures should be established for the application of competition law? (Khemani, 2003, p. 243). The opinions regarding the answers to these questions are divided. Some authors consider that liberalisation and the opening of economy, which stipulates the reduction of external barriers to imports in order to allow access to foreign goods on the domestic market and thus enable competition, is sufficient, and their opinion is that the law protecting the market competition is largely irrelevant. Furthermore, due to the actions of interest groups, meaning an arrangement between the domestic producers and the government, as well as the intentication of the public interest with the interest of domestic producers, the law that gets adopted can only have a "cosmetic character". Others, however, suggest that the policy of trade liberalisation has no predictable effects and that it is necessary to regulate the actions on the market in detail in order to protect the competition (Williams, 2005, p. 45). The question of goals and scope of competition law in different countries is discussed as well. Should the goal be defined as the protection of market competition, whereby it is necessary to make a distinction between the protection of market competition and the protection from competition? Should the goals be set broadly and range from public interest, restriction of economic power, protection of small and medium-sized enterprises, or should they be made concrete? What is clear is that the economy itself creates the justification for state interventions, and the governments create specific legislative instruments after political elections which intervene in the economy, so it is possible to conclude that as the policies change, rationale and implementation of the competition policy changes with it. Therefore, the EU, for example, has first determined the creation of a single market that covers the whole of EU as the goal, only to later define it as the consumer welfare. The USA had different goals in different periods, so it initially tried to protect the small and medium-sized enterprises (SME) only to later favour the economic efficiency as the goal. In the majority of jurisdictions of democratic countries, the politically popular goal today is the protection and welfare of the consumers. In terms 
of the scope of regulation and the question to whom the law applies, the prevailing opinion is that there should be a general law that applies on all economic activities and sectors, regardless if it is the case of economic entities in private or state ownership when they are engaged in commercial activities and when these activities prevent, disrupt, or restrict the competition on the market by having an impact on the reduction of efficiency and consumer welfare. In the majority of jurisdictions, standardised forms of prohibited business practices defined as prohibited agreements, misuse of the dominant position and excessive concentration have been adopted. The last open question for the countries in transition is related to the formation of institutions for the application of competition law whereby it is necessary to differentiate the public and private application of competition. In terms of establishing state institutions and agencies for the application of competition law, transitional countries have different experiences. However, what is almost common to all are the circumstances that prevent the establishment of efficient institutions for the application of competition law. The first obstacle that almost all transitional countries encountered is the absence of pro-market culture and competition law accordingly. This lack of experience is closely connected with the inability to utilise the potential benefits of competition. Equally so, as a consequence of inefficient experience, the majority of transitional countries cannot efficiently detect and prevent a large number of activities of economic entities that may be harmful to competition. The lack of experience with the free market often leads to situations where the non-market stakeholders make decisions on the price, entry into market, property rights and similar, or in some cases where certain economic entities, with or without state authorisation, can potentially monopolise the sale or purchase of specific goods. A particular problem, especially in the initial time period of formation of state agencies, is the lack of experts for the competition law, as well as material resources needed for the interpretation and application of competition law (Davidson, 2005, p. 74). In order for the agencies for the protection of market competition to be efficient in performing their competences, the transitional countries need to follow several principles (Khemani, 2003, p. 251):

a Agency for the protection of market competition needs to be independent and isolated from the political influence and accountable to an impartial body, for example the Parliament

b The separation between the process of investigation, criminal prosecution, and sentencing in the application of competition law

c The establishment of the system of verification and balance through legal remedies, for example the right to appeal

d Efficient and expeditious resolving of cases in order to reduce the costs of procedure, especially those that hamper the operation of economic entities

e The transparency of the procedure along with the protection of sensitive business information

$f$ The introduction of measures for the collection of data on relevant markets

g The procedure must have a juridist form

$\mathrm{h}$ There must be clear provisions in place that regulate the imposition of sanctions or other corrective measures which are considered necessary to deter/correct the consequences of violation of the law.

Bosnia and Herzegovina (hereinafter: $\mathrm{BiH}$ ), a country in transition and development, which did not inherit the culture of competition law as great economic powers did, faces specific challenges concerning adaptation and enforcement of competition law on its path towards full-fledged membership in the European Union. The area of market competition in post-Dayton BiH was an unknown thing, considering the fact that there was no tradition in terms of market competition, 
as well as no legal and regulatory framework in this field. Without technical, professional, and material support from the EU institutions, the transposition of rules and standards in the area of competition in $\mathrm{BiH}$ could not have been initiated. At the political level, the former European Community, meaning the current $\mathrm{EU}$, has asked for concrete results given that the EU is very sensitive in terms of competition and it asks for strict and consistent transposition of the competition rules into national legislations of countries aspiring for EU membership. The EU demands from EU membership candidate countries to harmonise the area of competition well before accepting them in its membership. Generally, a candidate country is obligated to create all necessary conditions for the functioning of legal and institutional framework that would be identical to the one in the EU at the moment of admission to the EU. However, in $\mathrm{BiH}$, the process concerning the introduction of modern competition law and its enforcement, meaning adaptation to the legal acquis, is conditioned by the complicated state and legal arrangement and represents a field of political determinism.

The subject of the paper is the analysis of the market competition protection system in Bosnia and Herzegovina in the context of harmonisation with the EU legal acquis and the efficiency of competition protection in the market of Bosnia and Herzegovina. It is evident that Bosnia and Herzegovina registers a very slow progress in terms of preparedness in the field of competition and that there is a certain inefficiency in the operation of the Council of Competition. The goal of this paper is to provide an answer to the question of what the cause of such condition is and to offer potential improvements. Considering the commitment of $\mathrm{BiH}$ to the membership in the $\mathrm{EU}$, also provided in the paper is a retrospective review of the European integration from the aspect of competition.

There are many researches and studies on the goals of competition law and policy and the importance and efficient application in the countries in development and transition. In line with that, Khemani (2003) carries out a comparative study of the economies of Central and Eastern Europe and Turkey from the aspect of EU enlargement effects. In his paper, he analyses the question of the establishment of legal infrastructure that encourages fair market competition. Cook, Fabella, and Lee (2007), raise the question what does the competition policy mean for the developing countries, and they critically analyse and examine how the different theoretical perspectives impact the policies of the developing countries. Mark Williams (2005) comprehensively examines the competition policy in China, Hong Kong, and Taiwan being the countries in transition, and in the context of influence of international organisations - WTO, OECD, UNCTAD, World Bank, and the IMF. Foster (2001) and Malinauskaite (2010) discuss the harmonisation of competition law in the context of globalisation and justifiability of the international competition law. The issue of the efficiency of competition protection agencies in the transition countries is discussed by Davidson (2005). Deša M. Tomić et al. (2006) provide an overview of the foundations of competition law in the $\mathrm{EU}$ and the progress of Croatia in terms of harmonisation with the legal acquis, which is of special importance for Bosnia and Herzegovina.

Methodology

Methodology used in the paper is characteristic of legal sciences and the dogmatic-normative method was used for the analysis of legal regulations that constitute the legal foundation of competition protection in $\mathrm{BiH}$ and the $\mathrm{EU}$, while the comparative method was used in terms of conformity assessment of the relevant positive regulations in $\mathrm{BiH}$ with the EU legal acquis. The analysis of BiH's EU integration process from the aspect of competition law and in terms of the development of the competition protection mechanism in $\mathrm{BiH}$ was conducted in line with the historical method. Teleological method was applied in order to carry out the interpretation of the legal norms contained in the relevant legal acts which comprise the legal foundation of 
the competition protection in the EU. Teleological method has enabled the understanding of the goal why these regulations were passed. Equally so, the application of this method has made it possible to determine whether the goal and meaning of legal regulations in the EU are contained in the legal order of $\mathrm{BiH}$.

When we talk about the European integration process, in the early 2000s, $\mathrm{BiH}$ was primarily focused on fulfilling the conditions of the Road Map, which was adopted in March 2000 and contained 18 guidelines for the integration of $\mathrm{BiH}$ into the European integration process. In terms of economic conditions carried by the Road Map, one was defined as the necessity to adopt the law on competition. Consequent to the aforementioned $\mathrm{BiH}$ has adopted the Law on Competition of $\mathrm{BiH}$ in 2001. The next step in the European integration process was to conduct the 'Feasibility study'. The work process on the Feasibility study was formally launched in March 2003, when the European Commission handed over the questionnaire with 346 questions covering the areas of economic and political arrangement of $\mathrm{BiH}$ and other areas relevant to the conclusion of the Stabilisation and Association Agreement to the Council of Ministers of $\mathrm{BiH}^{\prime}$. The Study had 16 priority areas, and priority $15^{2}$ stipulated the establishment of a regulatory body, Council of Competition of $\mathrm{BiH}$, which was carried out in 2004. In June 2004, the EU accepted the European Partnership with $\mathrm{BiH}$ (Council Decision, 2004), and the priorities were those from 16 priority areas. In October 2005, the Commission assessed that $\mathrm{BiH}$ achieved significant progress in implementing reforms from the Feasibility study and suggested the launch of negotiations on the conclusion of Stabilisation and Association Agreement, which took place in November 2005.

The signing of the Stabilisation and Association Agreement between the European Communities and their Member States, of the one part, and $\mathrm{BiH}$, of the other part (hereinafter: SAA), on 16 June $2008^{3}$, represents an international contract by which $\mathrm{BiH}$ acquires the status of potential candidate for membership in the EU. During the six-year transitional period of the SAA4, BiH is obligated to carry out gradual harmonisation of national legislation with the EU acquis in the most important areas related to the internal market. The process of harmonisation of legislation, in line with the SAA clause of active harmonisation, takes place with the assistance and monitoring of the joint bodies of $\mathrm{EU}$ and $\mathrm{BiH}$ formed in accordance with the provisions of the SAA, and this process also took place based on the previous Interim Agreement, which summarises some aspects of the SAA and which was in force from 1 July 2008 to 1 June 2015. Interim Agreement on Trade and Trade-related Matters had completely identical rules pertaining to competition and state assistance (Article 26 of the Interim Agreement is identical to Article 71 of the SAA). The Interim Agreement also encompassed the provisions on the liberalisation of trade and transport, as well as other important or even key aspects of the internal market (for example intellectual ownership rights and public procurement).

\footnotetext{
1 In November 2003, the EU approved the Feasibility Study that showed the readiness of BiH to undertake the next steps in the European integration process by opening negotiations on the conclusion of Stabilisation and Association Agreement. In this context, the Study identified 16 priority reform steps, which practically meant 41 new laws and 27 new institutions. 2 Priority number 15. Development of a single Bosnian and Herzegovinian economic space: establish the Competition Council; introduce provisions on the mutual recognition of products in the legal order of $\mathrm{BiH}$ and implement a consistent and effective public procurement regime throughout the country; remove all duplicate licences, permits and similar authorisation requirements to allow service providers (including financial institutions) to operate throughout $\mathrm{BiH}$ without having to fulfil unnecessary administrative requirements; create a single business registration system that is recognised throughout $\mathrm{BiH}$. 3 Entered into force on 1 June 2015.

4 The SAA entered into force on 1 June 2015 and the transitional period expires on 1 June 2021.
}

Retrospective overview of European integration from the aspect of competition 
The SAA has its politological ${ }^{5}$ and legal aspects, of which the following need to be highlighted: the clause of interpretative harmonisation and the clause of loyalty which the EU membership aspirant countries must abide by and continuously carry out precisely specified reforms. The EU's justification for demanding these reforms is in the fact that it sees itself as a supranational community with specific rules, which demand of the candidate countries to adapt to key features of the current membership (Analiza razvoja principa uslovljenosti EU, 2010).

The second particularity of the SAA is that it has the same nature of a 'mixed agreement', and the third particularity is defined as the purpose and goals of the SAA. The purpose of the SAA is the stabilisation and transition of BiH economy from ex-socialist (planned) to market economy, obligatory regional cooperation with other countries of the West Balkans, and possibility of admission to the EU membership (the EU is not obligated to respond positively to the application).

The goals of the SAA can be summarised as:

- establishment of political dialogue between the EU and BiH,

- launch of gradual harmonisation of national legislation with the EU legal acquis,

- regional cooperation within the Stabilisation and Association Process,

- promotion of economic relations of the two parties and

- gradual establishment of a free trade zone between the $\mathrm{EU}$ and $\mathrm{BiH}$, with the last two of these goals being precisely in the function of creating, conditionally speaking, a 'common market' between $\mathrm{BiH}$ and the $\mathrm{EU}^{6}$.

Specifics of the economic-legal system of $\mathrm{BiH}$ and the overall social-political environment had an effect on the country's ability to establish and guarantee a single economic space in $\mathrm{BiH}$. The fact that confirms the deficiency or inadequacy of the activities undertaken in developing a single economic space is that up until 2001, competition law and policy did not exist on state level, and the institutions that were supposed to ensure their enforcement were formed in early 2004. Therefore, the first steps towards the creation of a contemporary model of legal regulation of market competition as an instrument for the development and strengthening of a single market of $\mathrm{BiH}$ came due to foreign pressure expressed through the project entitled 'Single Economic Space in BiH'?

5 In politological sense, the SAA contains contextuality which is derived from

- Article 49 of the TEU: Any European State which respects the values referred to in Article 2 and is committed to promoting them may apply to become a member of the Union. The applicant State shall address its application to the Council, which shall act unanimously after consulting the Commission and after receiving the consent of the European Parliament, which shall act by a majority of its component members.

- from the Copenhagen Criteria - the Copenhagen Criteria are the conditions for EU membership, which were set at the meeting of the European Council in Copenhagen in 1993; and

- from various documents of the EU (decisions of the Council, agendas, European Commission reports and so on.), which plead to the candidate country to fulfil all conditions for the EU membership. Politological element is reflected in the fact that there is strong 'political pressure' for implementation of reforms of certain content and direction that would lead to final acceptance of the acquis. More details in: Analiza razvoja principa uslovljenosti EU (2010).

In political sense, the principle of conditionality is strongly pronounced and it is treated as the process of exchange between the EU and candidate country in which the EU offers a realistic perspective of membership if the candidate country implements a broad spectre of domestic reforms. The 'carrot and stick' approach in the principle of conditionality involves withdrawal/withholding of benefits from accession and suspension or deceleration of the process, if the government of the candidate country fails to achieve progress in negotiations.

6 More details in: Osnovni prikaz SSP (2008).

7 The project 'Single Economic Space' within the framework of CARDS programme was finalised in June 2005 and it was focused on three main economic areas: a) competition, b) protection of consumers and c) freedom of transport and industrial products safety. Activities of the project were created with the goal of assisting the development of a truly single market in Bosnia and Herzegovina, which represents an important step on the path towards European integration. 
Thanks to the first Law on Competition adopted in 2001, the Council of Competition was established on 1 May 2004 as an independent and autonomous body with exclusive competence in deciding on the presence of prohibited competition activities on the market of BiH. The LoC of 2001, which carried fundamental rules of competition based on articles 81 and 82 of the Treaty establishing the European Community (today's articles 101 and 102 of the Treaty on the Functioning of the EU), was not fully harmonised with the acquis from this field. This is why a new Law on Competition (hereinafter: LoC) was adopted in 2005.

The LoC is largely harmonised with the EU rules and regulations from the field of market competition, which ensures efficiency and transparency in its enforcement, simplifies procedures, and reduces the duration of certain stages of the procedure. The LoC has expanded and more precisely defined the competences of the Council of Competition with regard to performing administrative and professional affairs related to different aspects of protection of market competition. This also refers to the way of conducting the procedure, making the final decisions, sanction policy and duration of the procedure. Given the fact that LoC regulated some matters and concepts only principally, these matters are defined in more detail by the adoption of many by-laws. By-laws resulting from the LoC are partly harmonised and in compliance with appropriate secondary sources of the communautaire law.

The political system as a system of government and politics implies the process of creating and making decisions which, besides resolving the conflicts in institutions and between certain groups, also create preconditions for development and functioning of a social community. The political system is a subsystem of the social system that has a pronounced influence upon it. In terms of the relation of the political and economic system as a subsystem of the social system, it is possible to speak of two diametrically opposite approaches, which are the economic determinism and political (so-called conscious) determinism. According to the concept of economic determinism and historic materialism, the process of doing business and material conditions of life determine all processes in the society and that also includes the development of the social community as a whole. According to political determinism, the impact of the economic system on the development of the social community has a subsidiary significance due to the fact that in constellation of many factors, the political system has a dominant influence because the conscious realisation of changes is not limited by anything (Begić, 2000, p. 97). Therefore, political will and institutions are of key significance for creating preconditions for the economic development of a country.

When it comes to competition law in $\mathrm{BiH}$, the existence of political determinism is unquestionable. Namely, the absence of political will in the set modality of legal protection of market competition hampers further development of not only competition law both in terms of updating the normative framework and in terms of operation of the Council of Competition, which brings into question the realisation of said goals of modalities of legal protection of market competition in $\mathrm{BiH}$, meaning its overall progress towards EU membership.

Namely, the fact is that the last amendments of the LoC were carried out in 2009 and that there were no adequate activities in terms of updating the normative framework for almost a decade. Altogether, when observed within the framework of European integration, competition and many other fields in the period of 2010 to 2018 reflect the negative political tendencies that slow BiH down in the European integration process. Lack of consent of all key political stakeholders reflects on the competition policy as well. Characteristic of said period are several phenomena that ultimately negatively reflect on the creation of 'pro-European' system. Within the framework of drafting the Medium-Term Work Programme of the Council of Ministers of $\mathrm{BiH}$ for the period of
Reflection of absence of political will as proof of political determinism in $\mathrm{BiH}$ 
$2016-2018$, no activities related to amending the LoC were included in it, given the fact that the Council of Competition did dot state its exact opinion on this matter, avoiding to provide a direct answer. ${ }^{8}$ In addition to this law, some other laws that were planned were also not adopted, while by-laws are either not adopted or the timelines for their adoption are prolonged?

There is a practice being gradually introduced into political reality that by blocking the agreements on legislative harmonisation with the EU standards, regulations are adopted on entity level. The process of normative alignment and harmonisation between different levels of authority in $\mathrm{BiH}$ with the communautaire law has become difficult and slow. Realisation of planned obligations is in complete regression, especially on state level, because the legislative process in the Parliamentary Assembly of $\mathrm{BiH}$ is largely blocked and disabled ${ }^{10}$. At this stage, lack of coordination between state and entity parliaments and political disparity between the entities has become quite apparent. The European Commission concludes that it is necessary to improve cooperation between the legislative bodies on state, entity and the level of Brcko District $\mathrm{BiH}$, in order to ensure coordinated and harmonised alignment with the EU legislation throughout the territory of $\mathrm{BiH}$, and that the Parliamentary Assembly of $\mathrm{BiH}$ has made very little progress in adopting legal regulations related to the EU integration"1. The system of policy creation in $\mathrm{BiH}$ is still quite fragmented. There are autonomous policy planning systems present on state and entity level ${ }^{12}$.

Analysis of competition legislation in $\mathrm{BiH}$
When it comes to transposition of secondary sources of the EU competition law, and primarily the EU regulations, additional alignment is necessary with the following: ${ }^{13}$ Council Regulation (EC) No 1/2003 of 16 December 2002 on the implementation of the rules on competition laid down in Articles 81 and 82 of the Treaty, Council Regulation (EC) No 139/2004 of 20 January 2004 on the control of concentrations between undertakings, Commission Regulation (EC) No $773 / 2004$ of 7 April 2004 relating to the conduct of proceedings by the Commission pursuant to Articles 81 and 82 of the EC Treaty whose individual parts are still not transposed into competition legislation in $\mathrm{BiH}$. Also, it should be a priority need to transpose into $\mathrm{BiH}$ legislation the provisions of EU regulations referring to group exemptions of agreements in specific economic sectors such as: transport, insurance and distribution of motor vehicles, which means that it is necessary to transpose the Council Regulation (EC) No 169/2009 of 26 February 2009 applying rules of competition to transport by rail, road and inland waterway ${ }^{14}$, Commission Regulation (EU) No 267/2010 of 24 March 2010 on the application of Article 101(3) of the Treaty on the Functioning of the European Union to certain categories of agreements, decisions and concerted

8 Electronic correspondence between the Ministry of Foreign Trade and Economic Relations of $\mathrm{BiH}$ and the Council of Competition of BiH from 29 May 2015 and 2 June 2015.

9 The typical example are subordinate regulations of $\mathrm{BiH}$ from the field of technical legislation which are very important for consumer safety, where only five directives of the EU's New approach of the planned 29 were transposed into BiH legislation (directives on low voltage equipment, on machine safety, on electromagnetic compatibility, lifts and personal protection equipment), even though the deadline for transposition of all 29 directives of the EU was the end of 2008 (Monitoring of the BiH's European Integration Process: Annual Report, 2011, p. 22).

10 European Commission, 'Bosnia and Herzegovina Progress Reports' 2011, 2012, 2013 http://www.dei.gov.ba/dei/ bih_eu/paket/default.aspx?id=10098\&langTag=bs-BA (accessed 23 January 2019).

11 European Commission, 'Bosnia and Herzegovina Progress Reports' 2014 and 2015

http://www.dei.gov.ba/dei/bih_eu/paket/default.aspx?id=10098\&langTag=bs-BA (accessed 24 January 2019).

12 European Commission, ‘Bosnia and Herzegovina Progress Report' 2018 http://www.dei.gov.ba/dei/dokumenti/prosirenje/?id=19825 (accessed 24 January 2019).

13 From the report of EU experts within the IPA 2011 project 'Support to Enforcement of Regulations in the Field of Competition in BiH and Further Strengthening of Competition Policy, Including State Aid Component', 24 January 2014.

14 OJ L61/1. 
practices in the insurance sector ${ }^{15}$ and Commission Regulation (EU) No 461/2010 of 27 May 2010 on the application of Article 101(3) of the Treaty on the Functioning of the European Union to categories of vertical agreements and concerted practices in the motor vehicle sector ${ }^{16}$.

The main issue of the current LoC is contained in Article 24 which regulates the way of functioning and decision-making of this body. Council of Competition may make valid decisions if the session is attended by at least five members of the Council of Competition. Decisions of the Council of Competition are made by majority vote of members present, provided that at least one member of each constituent peoples must vote for each decision. A member of the Council of Competition may not abstain from voting. The obligation that 'at least one member of each of constituent peoples must vote for each decision' represents the main anomaly. According to Article 11 paragraph (2) of the LoC, if the Council of Competition does not issue a decision referred to in Article 41 paragraph (1) point c) of the LoC, it is deemed that the concluded agreement or the conduct of the undertaking is not abuse of dominant position. This may have far-reaching consequences for competition in $\mathrm{BiH}$ market, because if two members from two constituent peoples vote 'for' and two members from the third constituent people vote 'against', the decision cannot be made, which can be treated as a right of veto. This type of decision-making may also be the subject of political trade between members of the Council of Competition. Failure to reach a decision may also have its ethnic reasons that are above professional and legal reasons. This is the case of a typical example of ethnic determinism which is conceptually hypostatised in Article 24 and in conjunction with Article 22 of the LoC. The EU institutions also point to this problem through their recommendations. ${ }^{17}$

A particular specificity of the LoC also refers to Article 41 which regulates the duration of proceedings. The procedure for determining the violation of the law should not have time limitations, even though this is prescribed by law when it comes to prohibited agreements, determination of the individual exemptions, abuse of dominant position, and the assessment of concentration.

Based on annual work reports ${ }^{18}$, it can be seen that the Council of Competition has the basic task to ensure equal market conditions to company. The Council of Competition acts in the field of market competition by implementing the LoC with the corresponding by-laws, and it is particularly engaged on preventing the anticompetitive activities of company, which can be seen through the conclusion of prohibited contracts/agreements (cartel agreements), control of concentrations, and to prevent the abuse of dominant position of economic entities that aim to remove the competitors from the market.

Analysing the work of this institution based on its annual work reports, it is evident that the activities of the Council of Competition were also focused on establishing and improving cooperation with other state and regulatory bodies and institutions of Bosnia and Herzegovina.

15 OJ L83/1; Note, it is no longer in force, expiration date: 31 March 2017 so it is necessary to monitor which new regulation will replace this one.

16 OJ L129/52.

17 EU recommendations and operational conclusions - the first Subcommittee under the Stabilisation and Association Agreement (SAA) on Internal Market and Competition, including Consumer and Health Protection between the EU and $\mathrm{BiH}$, Brussels, 29 November 2016; EU recommendations and operational conclusions - the second Subcommittee under the Stabilisation and Association Agreement (SAA) on Internal Market and Competition, including Consumer and Health Protection between the EU and BiH, Mostar, 19 September 2017; - EU recommendations and operational conclusions the third Subcommittee under the Stabilisation and Association Agreement (SAA) on Internal Market and Competition, including Consumer and Health Protection between the EU and BiH, Brussels, 20 September 2018 - archive of the Ministry of Foreign Trade and Economic Relations.

18 Competition Council of Bosnia and Herzegovina, 'Reports', http://bihkonk.gov.ba/category/interni-akti/izvjestaji (accessed 21 January 2019).
Analysis of work of the Council of Competition as a regulatory body 
Table 1

Overview of received cases
The Council of Competition became a member of the International Competition Network (ICN) in mid-2005 and it also cooperates with the European Commission, OECD and UNCTAD. The Council of Competition has signed bilateral memorandums on cooperation and exchange of information with competition bodies of Croatia, Serbia, Macedonia and Bulgaria.

In the period from 1 May 2004 to the end of 2016 ${ }^{19}$, the Council of Competition has received 689 cases, most of which refer to applications concerning notification of concentration and giving expert opinions and interpretations of the Law on Competition and corresponding by-laws. A smaller number of cases refer to abuses of dominant position and prohibited agreements, while the numerically smallest number of cases refer to individual exemptions. The table below provides an overview of the number of cases by years and types.

\begin{tabular}{|c|c|c|c|c|c|c|c|c|c|c|c|c|c|}
\hline Year & 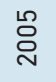 & ঃे & ळे & 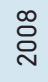 & 오 & 을 & $\overline{\bar{N}}$ & $\stackrel{\sim}{\sim}$ & $\stackrel{m}{\bar{N}}$ & $\stackrel{\text { Dे }}{\text { N }}$ & $\stackrel{\text { Ln }}{\stackrel{N}{N}}$ & సั & 莺 \\
\hline $\begin{array}{l}\text { Number of cases } \\
\text { by years }\end{array}$ & 14 & 39 & 60 & 75 & 62 & 52 & 56 & 53 & 79 & 87 & 62 & 50 & 689 \\
\hline $\begin{array}{l}\text { Notification of } \\
\text { concentration }\end{array}$ & 3 & 20 & 42 & 47 & 29 & 17 & 19 & 15 & 23 & 32 & 23 & 11 & 281 \\
\hline $\begin{array}{l}\text { Abuse of dominant } \\
\text { position }\end{array}$ & 2 & 3 & 3 & 6 & 6 & 9 & 5 & 4 & 13 & 13 & $16^{20}$ & $5^{21}$ & 85 \\
\hline $\begin{array}{l}\text { Prohibited } \\
\text { agreements }\end{array}$ & 2 & 1 & 5 & 4 & 7 & 5 & 4 & 12 & 13 & 18 & $1 / / / / /$ & $/ / / /$ & 71 \\
\hline $\begin{array}{l}\text { Individual } \\
\text { exemptions }\end{array}$ & 0 & 0 & 0 & 0 & 0 & 0 & 0 & 0 & 0 & 4 & 1 & 1 & 6 \\
\hline $\begin{array}{l}\text { Expert opinions } \\
\text { and various } \\
\text { interpretations of } \\
\text { the LoC }\end{array}$ & 7 & 15 & 10 & 18 & 20 & 21 & 28 & 22 & 30 & 20 & 22 & 33 & 246 \\
\hline
\end{tabular}

Source: Work reports of the Council of Competition (2005-2016)22

The Law on Competition has specified that the Council of Competition may impose a fine on undertakings in the amount ranging from $1 \%$ to $10 \%$ of the total income of the undertaking, as well as fines to responsible persons in undertakings. In the period of 2006-2016, the Council of Competition has imposed fines in total amount of BAM 8.676.132, 00 to companies that violated the rules of competition.

Administrative capacity of the Council of Competition with 26 employees in total is not sufficient to perform the assigned tasks. Additional training of the Council of Competition staff is required in order to increase its capacities to conduct investigations in specific cases. Increase

19 Ibid.

20 involves prohibited agreements; The Council of Competition Work Report for 2015 did not expressly state the number of cases involving prohibited agreement and abuses of dominant position

21 involves prohibited agreements; The Council of Competition Work Report for 2016 did not expressly state the number of cases involving prohibited agreement and abuses of dominant position

22 Competition Council of Bosnia and Herzegovina, 'Reports', http://bihkonk.gov.ba/category/interni-akti/izvjestaji (accessed 21 January 2019). 
in number of employees and their specialisation, carried out according to certain principles (for example, according to economic sectors or types of cases), would help the Council of Competition to strengthen its institutional capacities. In order to improve efficiency in the work on cases, additional training of employees is necessary, especially in techniques such as detecting cartels, carrying out sudden inspections, enforcing sanction mitigation policy, imposing sanctions, and carrying out economic analyses ${ }^{23}$.

Analysing the existing regulatory framework, it is possible to draw recommendations that would improve the existing modality of legal protection of market competition and that would stipulate activities in two directions, improvement of regulatory framework and activities, meaning the operation of the Council of Competition and of the Council of Ministers of BiH as follows: (Imamović-Čizmić, 2014, p. 108):

1 Since the last updating of the LoC was carried out way back in 2009, it would be purposeful and on the line of recommendations of the European Commission to approach the amending of the LoC as soon as possible. Namely, competition law and policy are one of constituent elements that serve to create the goal that can be expressed conceptually as a single market of $\mathrm{BiH}$. Further harmonisation and continuous alignment of $\mathrm{BiH}$ legislation with the EU legislation in this field is an order that must be fulfilled in order to join the EU. EU membership candidate country cannot negotiate on changes to the existing acquis communautaire, nor is there an option of non-transposing the appropriate legal acquis in the field of competition.

2 It is necessary to ensure consistent and proper enforcement of competition legislation primarily through institutional strengthening of the Council of Competition as the body that was given the task to implement this legislation.

3 In its work, the Council of Competition has mostly made decisions in specific cases upon request and less ex officio, and there is a justified need arising that this body should ex officio launch the procedure of investigating whether there is violation of regulations on competition, especially in the category of prohibited agreements (cartels) that are present on the $\mathrm{BiH}$ market (for example petroleum and petroleum derivatives).

4 The Council of Competition provides its opinion on the alignment of drafts and proposals of laws and other regulations from the fields that have an impact on market competition, which the proposers are obligated to deliver, with the LoC. There are many regulations of different levels of authority in $\mathrm{BiH}$ which directly or indirectly concern legal regulations from the field of competition (for example the Law on Telecommunications, laws on trade, laws on taxi transport... or autonomous general act of the employer and similar). In order to avoid discrepancies of other regulations with the Law on Competition, it is necessary for the Council of Competition to continuously warn other administrative bodies and other institutions of their obligation to ask for opinion on compliance of regulations with the Law on Competition, which may have an impact on competition.

5 The Council of Competition needs to work more on active promotion of competition law and policy in order for different target groups, such as sector regulators professional associations, small, medium and large-sized enterprises, business and industrial associations, chambers of commerce, consumer protection associations, academic community and so on, to become better acquainted with the postulates of modern market economy, meaning with applicative competition solutions, from which the consumers would benefit as well.

23 European Commission, 'Bosnia and Herzegovina Progress Reports', http://dei.gov.ba/dei/bih_eu/paket/default. aspx?id=10098\&langTag=bs-BA (accessed 21 January 2019).
Recommendations for improving the existing modality of legal protection of market competition 
6 Development and additional improvement of the leniency programme accompanied with training of the Council of Competition staff to successfully detect and process cartels, which builds and strengthens its credibility.

7 The Council of Competition should pay special attention to detecting cartels in sectors in which it is presumed they will first appear, having in mind that the research has shown that the cartels in countries in development and transition most commonly first appear in the public procurement sector;

8 The Council of Competition needs to adopt the practice of imposing strict sanctions for the violations of the LoC both for undertakings and responsible natural persons within undertakings, because it is considered that aggressive sanctioning policy is an efficient element in the fight against violations of the rules of competition;

9 The Council of Competition should carry out regular self-evaluation and assessment of the work on implementing the strategy of detection and processing of violations of the provisions of the LoC; in creating the strategy, the Council of Competition could use the SWOT analysis as a qualitative analytical method, which serves to present strengths, weaknesses, opportunities and threats through four factors in order to acquire the picture of the Council of Competition's potential. Such self-evaluation could serve as basis for drafting the UNCTAD's Voluntary Peer Review on Competition Policy, which is dedicated to improving the quality and efficiency of competition policy in the countries in development and transition;

10 The Council of Competition should introduce the practice of publishing the so-called 'black list' that would include those undertakings that carried out the harshest violations of the LoC, for example participated in a cartel or abused dominant position by discriminating the prices and the 'black list of managers' that would carry the names of punished responsible persons in undertakings. Introduction of this practice would result in prevention of violations of the LoC and greater awareness of all participants concerning the fact who the most common violators of its provisions are.

Conclusions

Protection of market competition has multivariable positive effects for consumers, undertakings and economy in general because it encourages efficiency and leads to increased social welfare. Realisation of this protection presupposes quality legal solutions and efficient enforcement by an independent, professional and well organised state body. At the same time, liberalisation of economic flows contributes to a more intense globalisation discourse that also brings standardisation of legal rules and policies by decreasing the economic sovereignty of countries in terms of creating the competition law. Globalisation demands a unified regime of competition law, because it represents an important element of state economic policy whereby the law on competition becomes an instrumentality for organising economic activities in an efficient manner. National legislations are standardised particularly in the domain of substantive competition law, while in the segment of enforcement of competition law the countries still have the freedom to choose the modalities. Most countries agree on the goals of the laws on competition, principles that encourage healthy competition policy, as well as appropriate means for the research and evaluation of business activities and transactions. Standardisation of legal rules is carried out within the framework of international institutions and integration and it is imminent because business is becoming increasingly global. The European Union rests on a single market, and this concept is sustainable only if there is strong mechanism of market competition protection in place. Members of the European Union harmonise their rules and become part of a complex mechanism of market competition protection. 
$\mathrm{BiH}$ is not a member of the European Union, it is on the path towards membership and belongs to one of the countries with smaller markets that is still in the initial stage of enforcement of modern competition laws. $\mathrm{BiH}$ is a complex country with highly complicated state-legal arrangement and division of competences. The Federation of $\mathrm{BiH}$ consists of cantons with their original constitutional competences, presumption of competence exists in the favour of entity in relation to the state of $\mathrm{BiH}$, and in the favour of cantons in the Federation of $\mathrm{BiH}$. Due to highly complex state arrangement of $\mathrm{BiH}$, whose Constitution has divided the competences between state and entity levels, the largest part of legal regulations regulating economic relations was adopted at entity level. The Law on Competition of BiHis adopted at state level but the whole mechanism of protection has a reflection of political determinism bearing in mind the election of members of the body in charge of enforcing competition law and the validity of its decisions. The Law on Competition of $\mathrm{BiH}$ is to the greatest extent compliant with acquis communautaire, based on which the legal framework of competition law was further elaborated by adopting a series of by-laws. However, the existing Law on Competition also has its flaws that actually hamper further development and progress of BiHin this field. This Law established the Council of Competition in $\mathrm{BiH}$, and its activities should contribute to the development of a single market. One of its primary tasks is to ensure preconditions for the realisation of competition of equal undertakings, with constant control of compliance of competition regulations and sanctioning of those who do not adhere to it. Efficiency and work results of the Council of Competition can also be measured by the number of decisions made, which prevent the activities of undertakings on the market that lead to conclusion of prohibited agreements, abuse of dominant position and concentration of undertakings with negative effects on the relevant market. Based on data obtained from the annual work reports, it is possible to conclude that the number of cases resolved before the Council of Competition is growing, but is still not sufficient to evaluate the work of this institution as successful, especially taking into account the nature of cases and the fact that not even one was initiated ex officio. The success of competition protection bodies primarily depends on the degree of their autonomy and professionalism and the quality of human resources. The Council has financial autonomy, but political autonomy is questionable having in mind the election and decision-making methods. In order for $\mathrm{BiH}$ to remain on the path towards membership in the European Union, it is necessary to undertake certain activities to improve the competition legislative framework in the sense of removing the shortcomings of political determinism and enhancing the work of the Council of Competition.

Analiza razvoja principa uslovljenosti EU. (2010). Sarajevo: Council of Ministers of $\mathrm{BiH}$ - the Directorate for European Integration.

Barack, B. (1981). The application of the competition rules (antitrust law) of the European Economic Community to enterprises and arrangements external to the common market. Boston: Kluwer. https://doi. org/10.1007/978-94-017-4482-9

Begić, K. (2000). Ekonomska politika. Sarajevo: Pravni fakultet.

Cook, P., Fabella R. V. \& Cassey Lee. (2007). Competitive Advantage and Competition Policy in Developing Countries. Cheltenham: Edward Elgar. https://doi. org/10.4337/9781847205339
Council Decision of 14 June 2004 on the Principles, Priorities and Conditions Contained in the European Partnership with BiH. (2004). OJ L221/10. https://doi. org/10.1007/s00330-004-2343-z

Davidson, K. M. (2005). Creating Effective Competition Institutions: Ideas for Transitional Economies. Asian-Pacific Law \& Policy Journal, 6(1), 71-129. Retrieved June 12, 2019 from http://blog.hawaii.edu/ aplpj/files/2011/11/APLPJ_06.1_davidson.pdf

European Commission. BiH Progress Reports. Retrieved January 21, 2019 from http://dei.gov.ba/dei/ bih_eu/paket/default.aspx?id=10098\&langTag=bs-BA Imamović-Čizmić, K. (2014). Market Competition Mechanism in Bosnia and Herzegovina. Saarbrücken: LAP Lambert Academic Publishing. 
Interim Agreement on Trade and Trade-related Matters between the European Communities and their Member States, of the one part, and $\mathrm{BiH}$, of the other part. (2008). Official Gazette of $\mathrm{BiH}$ - international contracts $5 / 08$.

Khemani, S. R. (2003). Competition Law and Policy in the Transitional Market Economies. In S. Togan \& V. N. Balasubramanyam (Eds.), Turkey and Central and Eastern European Countries in Transition Towards Membership of the EU (pp. 243-258). New York: Palgrave Macmillan. https://doi.org/10.1007/978-0-333-97800-9_11

The Law on Competition. (2001). Official Gazette BiH 30/01.

The Law on Competition. (2005, 2007, 2009). Official Gazette of $\mathrm{BiH}$ 48/05, 76/07 and 80/09.

Lundqvist, B. (2014). Standardization under EU Competition Rules and US Antitrust Laws, The Rise and Limits of Self-Regulation. Cheltenham: Edward Elgar Publishing. https://doi.org/10.4337/9781781954867 Lucio Lanucara, The Globalization of Antitrust Enforcement: Governance Issues and Legal Responses, Indiana Journal of Global Legal Studies, Volume 9 Issue 2, 2002,STR.443
Mlikotin Tomić, D. Horak, H., Šoljan, V., PecikotićKaufman, J. (2006). Europsko tržišno pravo. Zagreb: Školska knjiga.

Malinauskaite, J. (2010). Harmonisation of Competition Law in the Context of Globalisation .European Business Law Revie,

Monitoring of the BiH's European Integration Process: Annual Report for 2010. (2011). Sarajevo: Foreign Policy Initiative $\mathrm{BiH}$.

Ojala, M. The Competition law of Central and Eastern Europe ,Sweet Maxwell,1999.

Osnovni prikaz SSP. (2008). Sarajevo: Council of Ministers of $\mathrm{BiH}$ - the Directorate for European Integration.

Foster, S. E., (2001.) While America Slept: The Harmonization of Competition Laws Based upon the European Union Model, Emory International Law Review.

The Stabilisation and Association Agreement between the European Communities and their Member States, of the one part, and $\mathrm{BiH}$, of the other part. (2008). Official Gazette of $\mathrm{BiH} \mathrm{10/08.}$

Williams, M. (2005). Competition policy and law in China, Hong Kong and Taiwan. Cambridge: Cambridge University Press. https://doi.org/10.1017/ CB09780511494710

\section{About the} authors

\section{KANITA IMAMOVIĆ-ČIZMIĆ}

$\mathrm{PhD}$. Associate professor

University in Sarajevo, Faculty of Law

\section{Fields of interests}

Competition law, Economic anaylsis o law, Economic policy, Economic policy EU.

\section{Address}

Obala Kulina bana 7, 71000 Sarajevo, BiH

0038762347446

E-mail: k.imamovic-cizmic@pfsa.unsa.ba

\section{SAMIR SABLJICA}

\section{M.Sc}

Market Surveillance, Consumer Protection and Competition

\section{Address}

Ministry of Foreign Trade and Economic Relations of $\mathrm{BiH}$ 